\title{
https://doi.org/10.46344/JBINO.2020.v09i05.27
}

\section{THERAPEUTIC FIBRINOLYSIS WITH TPA FAILED BECAUSE TPA'S MECHANISM OF ACTION WAS MISUNDERSTOOD}

\author{
Victor Gurewich, MD
}

Director, Vascular Research Laboratory, Cambridge, MA, USA Professor of Medicine, Harvard Medical School

Email: vgurewich@tsillc.net

Date of Acceptance: $27^{\text {th }}$ August 2020 Date of Publish: 04 ${ }^{\text {st }}$ September 2020 )

\begin{abstract}
Therapeutic fibrinolysis has used tissue plasminogen activator (tPA) since 1987 based on the belief that TPA was alone responsible for fibrinolysis. This was, however belied by clinical experience with TPA as well as experimental findings showing that fibrinolysis required both biological activators. In the clinic, it was never possible to show that tPA was more effective than the previous activator, streptokinase (SK), despite comparative mega trials in acute myocardial infarction (AMI) in which the only significant difference found was that TPA caused more intracranial hemorrhage $(\mathrm{ICH})$ than SK. Eventually, this experience with IPA resulted in TPA as well as fibrinolysis being discredited and replaced by percutaneous coronary intervention (PCI) whenever possible. In ischemic stroke, fibrinolysis with IPA remains the standard. By contrast, the endogenous, physiological system induces fibrinolysis with both TPA and urokinase plasminogen activator (UPA). The native form of UPA is a proenzyme, prouPA, and TPA and prouPA have complementary modes of action making them synergistic in combination. This combination was once tested clinically in 101 AMI patients who were given a mini bolus of TPA $(5 \mathrm{mg})$ followed by a modest infusion of prouPA. Compared with the results in the best of the tPA trials, this combination regimen almost doubled the infarct artery TMI-3 patency rate and reduced the mortality rate six-fold. The findings are a testimony to the therapeutic potential of the endogenous paradigm of fibrinolysis compared with current monotherapy.
\end{abstract}

\section{Keywords: Nil}




\section{Introduction}

The science philosopher, Thomas Kuhn, showed that "Science does not progress as a linear accumulation of new knowledge, but undergoes periodic revolutions called paradigm shifts." The paradigm from a well-established method is resisted, explaining why tPA treatment has persisted for so long despite not working well, and as a result, scientific progress is stalled. No change has occurred since 1987, despite a consensus that IPA is inadequate and its $\mathrm{ICH}$ complication risk is significant.

Instead, the treatment of choice has become $\mathrm{PCl}$, which delays reperfusion significantly and precludes optimal salvage of myocardial and brain function. There are two plasminogen activators involved in the biological fibrinolysis, rather than only one. The other, UPA, the native form of which is a proenzyme, prouPA. IPA and prouPA have complementary modes of action are synergistic, which gives them an effect superior to that of either one alone.

The TPA clinical experience provides little support for its singular role in fibrinolysis. Even after comparative trials in 95,740 patients with AMI [1-3], it was not possible to establish that TPA was better than SK [4]. In these studies, the TPA dose used gave a plasma concentration about 1,000 fold higher than its physiological one, which was expected to be highly effective. Although the trial results contradicted the expectations and were not consistent with the IPA hypothesis, no explanation for the paradoxical findings was offered and TPA remained the unquestioned fibrinolytic of choice.
It is evident that a more effective and safer fibrinolytic regimen is needed.

\section{Fibrinolysis requires both biological plasminogen activators is the obvious answer}

Gene deletion studies

Gene knockout studies in mice showed that deleting the TPA gene had no measurable inhibiting effect on lysis of an intravascular clot and did not induce significant spontaneous fibrin deposition. By contrast, when the UPA gene was deleted, both inhibition of clot lysis and spontaneous fibrin deposition occurred. When both genes were deleted, a significantly stronger effect on both of these measures took place. The investigators concluded that both activators were required for a full fibrinolytic effect [5] but that UPA rather than TPA had the dominant effect $[5,6]$. This finding reflects UPA having two functional states, single-chain proenzyme and two-chain enzyme, whereas tPA's single and two-chain forms have the same activities [8]. Although the gene deletion studies were published as much as 20 years ago in prominent journals, the findings were ignored.

Their complementary modes of action requires both for an optimal effect

Clot lysis studies in human plasma were consistent with the gene deletion studies. For example, the double gene knockout effect is explained by TPA and prouPA's complementary modes of action [17], so that both are needed for a complete affect and they have a synergistic fibrinolytic effect in combination 
[18]. [18]. In a recent study, this synergistic effect was shown to be promoted almost two-fold when the activators were used sequentially, starting with TPA [19].

This is also how the endogenous system functions in which fibrinolysis is initiated by TPA when it is released from the vessel wall at the site a thrombus, and is continued by prouPA in the blood that is activated to tcuPA during lysis. Although some of these finding go back almost 30 years, fibrinolytic therapy with TPA alone continued without ever being put into question.

Clinical corroboration of the sequential combination effect

A sequential administration of the two activators was once tested in 101 patients with AMI. In the first 10 patients, a $10 \mathrm{mg}$ bolus of tPA was given to initiate lysis, which turned out to be excessive and so only a $5 \mathrm{mg}$ bolus (5\% of the standard tPA dose) was given to the remaining 91 patients. This was followed by an infusion of prouPA, $40 \mathrm{mg} / \mathrm{h}$ for 90 minutes [34]. This combination induced a TIMI-3 patency at $24 \mathrm{~h} 82 \%$ of the 28 patients re-catheterized at that time, the overall mortality was $1 \%$. This compares favorably with the best results in the TPA trials in which the TIMI-3 patency at $24 \mathrm{~h}$ was $45 \%$ and the mortality was $6.3 \%$ [3].

Despite this high infarct artery patency and 6-fold reduction in mortality by this combination, the study had no effect on fibrinolytic therapy with TPA alone, and a second study was never done. This was because the pharmaceutical company developing prouPA was sold to Pharmacia which decided to discontinue its cardiovascular product line.

Endogenous fibrinolysis utilizes both activators

The endogenous fibrinolytic system functions efficiently with a TPA plasma concentration of only $10-12 \mathrm{ng} / \mathrm{mL}$, much of which is in an inactive complex with its inhibitor, plasminogen activator inhibitor-1 (PAI-1) [20]. Nevertheless, lysis is sufficient to generate a concentration of $112-250$ $\mathrm{ng} / \mathrm{mL}$ of $\mathrm{D}$-dimer in normal individuals. Since D-dimer represents $\sim 60 \%$ of the fibrin monomer mass, this plasma concentration represents a steady state level of fibrin degradation of $\sim 1 \mathrm{mg}$ of fibrin. In patients with thromboembolism, D-dimer levels of $\geq$ $5,000 \mathrm{ng} / \mathrm{mL}$ are found, corresponding to of $\geq 25 \mathrm{mg}$ of fibrin being degraded. In $15 \%$ of patients with AMl, the coronary thrombus responsible for the infarct was absent by the time the patient came to catheterization for primary $\mathrm{PCl}$ [22], representing the rate of endogenous fibrinolysis. This spontaneous TIMI-3 patency rate compares with one only three-fold greater at $24 \mathrm{~h}$ by IPA at a therapeutic concentration [3].

The efficacy of endogenous fibrinolysis cannot be explained by the small amount of TPA available alone, most of which is in an inactive inhibitor complex with PAI-1. Instead, it can be explained by the sequential effects of both activators in a synergistic combination, which is also consistent with findings from gene deletion findings $[5,6]$ and clot lysis studies $[15,16]$. since proupA is a proenzyme, it is not inhibited by plasma PAl-1, although there is little prouPA in plasma, most of it is carried by platelets [16] and monocytes [33], which gives it a longer plasma half-life. 
The molecular function of biological fibrinolysis

The source of TPA in fibrinolysis is the vessel wall where it is stored and from where it is released at the site of an intravascular fibrin thrombus. The tPA then binds to the fibrin thrombus due to its exceptionally high affinity, a property which sets IPA apart from other plasma proteins [1]. The unbound IPA is rapidly cleared from the circulation (T1/2 5 min) or is inhibited by PAI-1, suggesting that free IPA is hazardous, which it is to hemostatic fibrin to which it can bind resulting in its disruption. This is the principle cause of bleeding during TPA therapy [33].

Therefore, TPA activates the first plasminogen on intact fibrin and prouPA and tcuPA the remaining two which are on partially degraded fibrin. Since tPA has only the single binding site at which fibrinolysis is initiated, it cannot activate the other two plasminogens, which are activated, in fact, by UPA.

Thus, tPA's specificity is to plasminogen on the D-domain of intact fibrin where the ternary complex is formed whereas prouPA's specificity is to plasminogen on the E-domain of partially degraded fibrin where the conformational change occurs. This fibrin-domain specificity was confirmed by a kinetic study with isolated fibrin fragments $D$ and $E$. Plasminogen activation by TPA was promoted only by fibrin fragment-D and that by prouPA was promoted only by the fibrin fragment-E [12], confirming that their fibrinolytic effects are complementary and sequential. Both are required for a full effect to be also fibrin-specific so that bleeding complications are minimized or eliminated.

\section{Conclusions}

Prompt reperfusion of a thrombus blocked artery is essential for optimal salvage of heart or brain function and to achieve the lowest mortality. This is possible only with thrombolysis, which is a simple outpatient treatment. However, tPA alone is ineffective and hazardous due to the large doses required. $\mathrm{PCl}$ is too timeconsuming. Fibrinolysis based on the natural fibrinolytic paradigm is highly effective and is safe due to the lower doses required by synergy. The efficacy of a sequential combination of a TPA bolus followed by a prouPA infusion was previously demonstrated in $101 \mathrm{AMI}$ patients [18]. This doubled the infarct artery patency rate and reduced mortality 6-fold. A paradigm shift in the management of therapeutic fibrinolysis is long over-due. 
References

\section{Husain SS, Lipinski B, Gurewich V.} Rapid purification of high affinity plasminogen activator from human plasma by specific adsorption on fibrincelite. Proc Nat Acad Sci (USA) 1981; 78: 4265-4269.

2. Vassalli JD, Baccino D, Belin D: A cellular binding site for the Mr 55,000 form of the human plasminogen activator, urokinase. J Cell Biol 1985; 100: 86-92.

3. Collen D. The plasminogen (fibrinolytic) system. Thromb Haemost 1999; 82: 259-70.

4. Longstaff C, Kolev K. Basic mechanisms and regulation of fibrinolysis. J Thromb Haemostas 2015; 13: S98-S105.

5. Gruppo Italiano Per Lo Studio Della Sopravvivenza Nell'Infarto Miocardico. GISSI-2: A factorial randomised trial of alteplase versus streptokinase and heparin versus no heparin among 12,490 patients with acute myocardial infarction. Lancet 1990; 336: 65-75.

6. ISIS-3 Third International Study of Infarct Survival Collaborative Group. ISIS-3: a randomized comparison of streptokinase vs tissue plasminogen activator vs anistreplase and of aspirin plus heparin vs aspirin alone among 41,299 cases of suspected acute myocardial infarction. Lancet 1992; 339: 65-71.

7. The GUSTO Angiographic Investigators. The effects of tissue plasminogen activator, streptokinase, or both on coronary-artery patency, ventricular function, and survival after acute myocardial infarction. N Engl J Med 1993; 329: 1615-22.
8. Brophy JM, Joseph L. Placing trials in context using Bayesian analysis. GUSTO revisited by Reverend Bayes. JAMA 1995; 273: 871-75.

9. Brodie, et al, AMJC, 2000).

10. Assessment of the Safety and Efficacy of a New Treatment Strategy with Percutaneous Coronary Intervention (ASSENT-4 PCI) Investigators. Primary versus tenecteplase-facilitated percutaneous coronary intervention in patients with STsegment elevation of acute myocardial infarction (ASSENT-4 PCI): randomized trial. Lancet 2006; 367: 569-578.

11. Deluca G, Ernst N, Zijlstra F, van't Hof AWJ, Hoorntje JCA, Dambrink JHE, Gosslink ATM, de Boer MJ, Surjapranata $H$. Preprocedural TIMI flow and mortality in patients with acute myocardial infarction treated by primary angioplasty. J Am Coll Cardiol 2004; 43: 1363-1367.

12. Bugge TH, Flick MJ, Danton MJS, Daugherty CC, Rømer J, Danø K, Carmeliet P, Collen D, Degen JL. Urokinase-type plasminogen activator is effective in fibrin clearance in the absence of its receptor or tissue-type plasminogen activator. Proc Natl Acad Sci USA 1996; 93: 5899-5904.

13. Singh I, Burnand KG, Collins $M$, Luttun A, Collen D, Boelhouwer B, Smith A. Failure of thrombus to resolve in urokinase-type plasminogen activator gene-knockout mice: rescue by normal bone marrowderived cells. Circulation 2003; 107: 869-75.

14. Rijken DC, Hoylaerts $M$, Collen D. Fibrinolytic properties of one-chain and two-chain human extrinsic (tissue-type) plasminogen activator. J Biol Chem 1982; 257: $2920-25$. 
15. Pannell R, Black J, Gurewich V. The complementary modes of action of tissue plasminogen activator (t-PA) and prourokinase (pro-UK) by which their synergistic effect on clot lysis may be explained. J Clin Invest 1988; 81: 853-59.

16. Gurewich V, Pannell R. Synergism of tissue-type plasminogen activator (t-PA) and single-chain urokinase-type plasminogen activator (sCU-PA) on clot lysis in vitro and a mechanism for this effect. Thromb Hemost 1987; 57: 372-78.

17. Pannell R, Li S, Gurewich V. Fibrinspecific and effective clot lysis requires both plasminogen activators and for them to be in a sequential rather than simultaneous combination. J Thromb Thrombolysis (in press).

18. Zarich SW, Kowalchuk GJ, Weaver WD, Loscalzo J, Sassower M, Manzo K, Byrnes C, Muller JE, Gurewich V for the PATENT Study Group. Sequential combination thrombolytic therapy for acute myocardial infarction: results of the pro-urokinase and t-PA enhancement of thrombolysis (PATENT) trial. J Am Coll Cardio 1995; 26: 374-79.

19. new ref - no author yet

20. Chandler WL, Jascur $\mathbf{M L}$, Henderson PJ. Measurement of different forms of tissue plasminogen activator in plasma. Clin Chem 2000; 46: 38-46.

21. Assessment of the Safety and Efficacy of a New Treatment Strategy with Percutaneous Coronary Intervention (ASSENT-4 PCI) investigators. Primary versus tenecteplase-facilitated percutaneous coronary intervention in patients with STsegment elevation acute myocardial infarction (ASSENT-4 PCI): randomised trial. Lancet $2006 ; 367$ : 569-78.

22. Gurewich V, Emmons F, Pannell R. Spontaneous clot lysis in whole human plasma by endogenous tissue type and urokinase type plasminogen activators: demonstration of a promoting effect by $t^{-}$ PA and by platelets on urokinase. Fibrinolysis 1988; 2: 143-49.

23. Grau E, Moroz LA. Fibrinolytic activity of normal human blood monocytes. Thromb Res 1989; 53: 145-62.

24. Schielen WJG, Adams HPHM, Voskuilen $M$, Tesser GJ, Nieuwenhuizen W. Structural requirements of position Aa-157 in fibrinogen for the fibrin-induced rate enhancement of the activation of plasminogen by tissue-type plasminogen activator. Biochem J 1991; 276: 655-59.

25. Voskuilen $M$, Vermond $A$, Veeneman GH, van Boom JH, Klasen EA, Zegers ND, Nieuwenhuizen $\mathbf{W}$. Fibrinogen lysine residue Aa157 plays a crucial role in the fibrin-induced acceleration of plasminogen activation, catalyzed by tissue-type plasminogen activator. J Biol Chem 1987; 262: 5944-46.

26. Hoylaerts $M$, Rijken DC, Lijnen HR, Collen D. Kinetics of the activation of plasminogen by human tissue plasminogen activator. Role of fibrin. J Biol Chem 1982; 257: 2912-19.

27. Harpel PC, Chang TS, Verderber E. Tissue plasminogen activator and urokinase mediate the binding of Gluplasminogen to plasma fibrin I. Evidence for new binding sites in plasmin-degraded fibrin I. J Biol Chem 1985; 260: 4432 (abstr).

28. Suenson E, Lützen O, Thorsen S. Initial plasmin-degradation of fibrin as the basis 
of a positive feed-back mechanism in fibrinolysis. Eur J Biochem 1984; 140: 513-22.

29. Liu J, Gurewich V. Fragment E-2 from fibrin substantially enhances pro-urokinaseinduced glu-plasminogen activation. A kinetic study using a plasmin-resistant mutant pro-urokinase (Ala-158-rpro-UK). Biochemistry 1992; 31: 6311-17.

30. Petersen LC. Kinetics of reciprocal pro-urokinase/plasminogen activation. Stimulation by a template formed by the urokinase receptor bound to poly (Dlysine). Eur J Biochem 1997; 245: 316-23.

31. Liu J, Pannell R, Gurewich V. A transitional state of pro-urokinase which has a higher catalytic efficiency against glu-plasminogen than urokinase. J Biol Chem 1992; 267: 15289-92.

32. Vaughan DE, Vautloutle E, Collen D. Urokinase binds to platelets through a specific saturable, low affinity mechanism. Fibrinolysis 1990; 4: 141.

33. Marder VJ, Sherry S. Thrombolytic therapy: current status. $N$ Engl J Med 1988; 318: 1512-1520.

34. Liu J, Gurewich V. A comparative study of the promotion of tissue plasminogen activator and pro-urokinaseinduced plasminogen activation by fragments D and E-2 of fibrin. J Clin Invest 1991; 88: 2012-17.

35. Pannell R, Gurewich V. Pro-urokinase - a study of its stability in plasma and a mechanism for its selective fibrinolytic effect. Blood 1986; 67: 1215-23.

36. Gurewich V, Pannell R. Inactivation of single chain urokinase (pro-urokinase) by thrombin and thrombin-like enzymes: relevance of the finding to the interpretation of fibrin binding experiments. Blood 1987; 69: 769-72.

37. Gurewich V, Johnstone M, Loza JP, Pannell R. Pro-urokinase and prekallikrein are both associated with platelets: implications for the intrinsic pathway of fibrinolysis and for therapeutic thrombolysis. FEBS Lett 1993; 318: 317-2

Pannell R, Gurewich V. A comparison of the rates of clot lysis in a plasma milieu induced by tissue plasminogen activator (t-PA) and recprourokinase: evidence that t-PA has a more restricted mode of action. Fibrinolysis 1992; 6: 1-5.

Medved L, Nieuwenhuizen W. Molecular mechanisms of initiation of fibrinolysis by fibrin. Thromb Haemost 2003; 89: 409-19.

Baglin TP, Landown R, Frasson R, Huntington JA. Discovery and characterization of an antibody directed against exosite 1 of thrombin. J Thromb Haemos 2016 ; 14: 137-42.

1. Gruppo Italiano Per Lo Studio Della Sopravvivenza Nell'Infarto Miocardico. GISSI-2: A factorial randomised trial of alteplase versus streptokinase and heparin versus no heparin among 12,490 patients with acute myocardial infarction. Lancet 1990; 336: 65-75.

2. ISIS-3 Third International Study of Infarct Survival Collaborative Group. ISIS-3: a randomized comparison of streptokinase vs tissue plasminogen activator vs anistreplase and of aspirin plus heparin vs aspirin alone among 41,299 cases of suspected acute myocardial infarction. Lancet 1992; 339: 65-71. 
3. The GUSTO Angiographic Investigators. The effects of tissue plasminogen activator, streptokinase, or both on coronary-artery patency, ventricular function, and survival after acute myocardial infarction. N Engl J Med 1993; 329: 1615-22.

4. Brophy JM, Joseph L. Placing trials in context using Bayesian analysis. GUSTO revisited by Reverend Bayes. JAMA 1995 ;273: 871-75.

5. Bugge TH, Flick MJ, Danton MJS, Daugherty CC, Rømer J, Danø K, Carmeliet $P$, Collen $\mathbf{D}$, Degen JL. Urokinase-type plasminogen activator is effective in fibrin clearance in the absence of its receptor or tissue-type plasminogen activator. Proc Natl Acad Sci USA 1996; 93: 5899-5904.

6. Singh I, Burnand KG, Collins $M$, Luttun A, Collen D, Boelhouwer B, Smith A. Failure of thrombus to resolve in urokinase-type plasminogen activator gene-knockout mice: rescue by normal bone marrowderived cells. Circulation 2003; 107: 869-75.

7. Pannell R, Gurewich V. A comparison of the rates of clot lysis in a plasma milieu induced by tissue plasminogen activator (t-PA) and recprourokinase: evidence that t-PA has a more restricted mode of action. Fibrinolysis 1992; 6: 1-5.

8. Rijken DC, Hoylaerts $M$, Collen D. Fibrinolytic properties of one-chain and two-chain human extrinsic (tissue-type) plasminogen activator. J Biol Chem 1982; 257: 2920-25.

9. Voskuilen $\mathbf{M}$, Vermond $A$, Veeneman GH, van Boom JH, Klasen EA, Zegers ND, Nieuwenhuizen $\mathbf{W}$. Fibrinogen lysine residue Aa157 plays a crucial role in the fibrin-induced acceleration of plasminogen activation, catalyzed by tissue-type plasminogen activator. J Biol Chem 1987; 262: 5944-46.

10. Schielen WJG, Adams HPHM, Voskuilen M, Tesser GJ, Nieuwenhuizen W. Structural requirements of position Aa-157 in fibrinogen for the fibrin-induced rate enhancement of the activation of plasminogen by tissue-type plasminogen activator. Biochem J 1991; 276: 655-59.

11. Medved L, Nieuwenhuizen $\mathbf{W}$. Molecular mechanisms of initiation of fibrinolysis by fibrin. Thromb Haemost 2003; 89: 409-19.

12. Liu J, Gurewich V. A comparative study of the promotion of tissue plasminogen activator and pro-urokinaseinduced plasminogen activation by fragments $D$ and E-2 of fibrin. J Clin Invest 1991; 88: 2012-17.

13. Hoylaerts $M$, Rijken DC, Lijnen HR, Collen D. Kinetics of the activation of plasminogen by human tissue plasminogen activator. Role of fibrin. J Biol Chem 1982; 257: 2912-19.

14. Vaughan DE, Vautloutle E, Collen D. Urokinase binds to platelets through a specific saturable, low affinity mechanism. Fibrinolysis 1990; 4: 141.

15. Gurewich V, Johnstone M, Loza JP, Pannell R. Pro-urokinase and prekallikrein are both associated with platelets: implications for the intrinsic pathway of fibrinolysis and for therapeutic thrombolysis. FEBS Lett 1993; 318: 317-21.

16. Gurewich V, Emmons F, Pannell R. Spontaneous clot lysis in whole human plasma by endogenous tissue type and urokinase type plasminogen activators: 
demonstration of a promoting effect by $t-$ PA and by platelets on urokinase. Fibrinolysis 1988; 2: 143-49.

17. Pannell R, Black J, Gurewich V. The complementary modes of action of tissue plasminogen activator (t-PA) and prourokinase (pro-UK) by which their synergistic effect on clot lysis may be explained. J Clin Invest 1988; 81: 853-59.

18. Gurewich V, Pannell R. Synergism of tissue-type plasminogen activator ( $t-P A)$ and single-chain urokinase-type plasminogen activator (scu-PA) on clot lysis in vitro and a mechanism for this effect. Thromb Hemost 1987; 57: 372-78.

19. Pannell R, Li S, Gurewich V. Fibrinspecific and effective clot lysis requires both plasminogen activators and for them to be in a sequential rather than simultaneous combination. J Thromb Thrombolysis (in press).

20. Chandler WL, Jascur ML, Henderson PJ. Measurement of different forms of tissue plasminogen activator in plasma. Clin Chem 2000; 46: 38-46.

21. Baglin TP, Landown $R$, Frasson $R$, Huntington JA. Discovery and characterization of an antibody directed against exosite 1 of thrombin. J Thromb Haemos 2016; 14: 137-42.

22. Assessment of the Safety and Efficacy of a New Treatment Strategy with Percutaneous Coronary Intervention (ASSENT-4 PCI) investigators. Primary versus tenecteplase-facilitated percutaneous coronary intervention in patients with STsegment elevation acute myocardial infarction (ASSENT-4 PCI): randomised trial. Lancet 2006; 367: 569-78.
23. Harpel PC, Chang TS, Verderber E. Tissue plasminogen activator and urokinase mediate the binding of Gluplasminogen to plasma fibrin I. Evidence for new binding sites in plasmin-degraded fibrin I. J Biol Chem 1985; 260: 4432 (abstr).

24. Suenson E, Lützen $\mathbf{O}$, Thorsen $\mathbf{S}$. Initial plasmin-degradation of fibrin as the basis of a positive feed-back mechanism in fibrinolysis. Eur J Biochem 1984; 140: 513-22.

25. Liu J, Gurewich V. Fragment E-2 from fibrin substantially enhances pro-urokinaseinduced glu-plasminogen activation. A kinetic study using a plasmin-resistant mutant pro-urokinase (Ala-158-rpro-UK). Biochemistry 1992; 31: 6311-17.

26. Petersen LC. Kinetics of reciprocal pro-urokinase/plasminogen activation. Stimulation by a template formed by the urokinase receptor bound to poly (Dlysine). Eur J Biochem 1997; 245: 316-23.

27. Liu J, Pannell R, Gurewich V. A transitional state of pro-urokinase which has a higher catalytic efficiency against glu-plasminogen than urokinase. J Biol Chem 1992; 267: 15289-92.

28. Pannell R, Gurewich V. Pro-urokinase - a study of its stability in plasma and a mechanism for its selective fibrinolytic effect. Blood 1986; 67: 1215-23.

29. Vassalli JD, Baccino D, Belin D: A cellular binding site for the Mr 55,000 form of the human plasminogen activator, urokinase. J Cell Biol 1985; 100 :86-92.

30. Collen D. The plasminogen (fibrinolytic) system. Thromb Haemost 1999; 82: 259-70. 
31. Longstaff C, Kolev K. Basic mechanisms and regulation of fibrinolysis. J Thromb Haemostas 2015; 13: S98-S105.

32. Gurewich V, Pannell R. Inactivation of single chain urokinase (pro-urokinase) by thrombin and thrombin-like enzymes: relevance of the finding to the interpretation of fibrin binding experiments. Blood 1987; 69: 769-72.

33. Grau E, Moroz LA. Fibrinolytic activity of normal human blood monocytes. Thromb Res 1989; 53: 145-62.
34. Zarich SW, Kowalchuk GJ, Weaver WD, Loscalzo J, Sassower M, Manzo K, Byrnes C, Muller JE, Gurewich V for the PATENT Study Group. Sequential combination thrombolytic therapy for acute myocardial infarction: results of the pro-urokinase and t-PA enhancement of thrombolysis (PATENT) trial. J Am Coll Cardio 1995;

26:

374-79. 